\title{
Rancang Bangun Film Animasi 3 Dimensi Universitas Sam Ratulangi
}

\author{
Yunita Caroline Umpenawany $^{1 *}$, Virginia Tulenan ${ }^{2}$, Brave A. Sugiarso ${ }^{3}$ \\ 1,2,3 Program Studi Teknik Informatika, Fakultas Teknik, Universitas Sam Ratulangi \\ E-mail :120216010@student.unsrat.ac.id ${ }^{1}$, virginia.tulenan@unsrat.ac.id ${ }^{2}$, brave@unsrat.ac.id ${ }^{3}$
}

\begin{abstract}
Abstrak- Universitas Sam Ratulangi (Unsrat) merupakan salah satu perguruan tinggi terbaik di Manado. Popularitas Unsrat cukup tinggi melihat banyaknya jumlah mahasiswa baik dari dalam maupun dari luar daerah dan diperkirakan akan terus bertambah setiap tahunnya. Hal ini cukup baik untuk pertumbuhan dan perkembangan Unsrat. Walaupun populer, masih banyak masyarakat termasuk mahasiswa Unsrat sendiri yang masih belum begitu mengetahui letak gedung-gedung di Unsrat.

Begitu pesatnya perkembangan Teknologi yang mencakup segala bidang, salah satunya dalam bidang Multimedia seperti Animasi dapat dimanfaatkan untuk mengatasi permasalahan tersebut. Dengan penggunaan multimedia, penyampaian informasi akan menjadi lebih menarik dan mempermudah pengguna dalam mendapatkan informasi. Berdasarkan tujuannya, penelitian ini berhasil menampilkan bangunanbangunan di Unsrat dalam bentuk film Animasi 3D. Film Animasi 3D ini dapat menjadi wadah pengenalan kampus Unsrat. Terdapat tiga tahap pembuatan film animasi 3D diawali dengan pra produksi, produksi, hingga pasca produksi. Pembuatan Film Animasi ini menggunakan tools Blender 2.71 dan Adobe Premiere Pro CS6.

Beberapa hal yang harus diperhatikan adalah gunakan hardware yang memadai seperti komputer cluster untuk mempercepat proses rendering. Lakukan observasi serta dokumentasikan melalui foto objek yang akan di modeling agar hasilnya bisa nampak realistis ataupun sesuai dengan yang diinginkan. Untuk peta pada animasi, gunakan latar google earth atau tampilan yang lebih real
\end{abstract}

Kata kunci - Adobe Premiere, Animasi 3D, Blender, Gedung, Unsrat

\section{PENDAHULUAN}

Teknologi Informasi (TI) adalah studi atau peralatan elektronika, terutama komputer, untuk menyimpan, menganalisa, dan mendistribusikan informasi apa saja, termasuk kata-kata, bilangan, dan gambar (kamus Oxford, 1995). Zaman sekarang TI berkembang dengan sangat pesat serta mencakup segala bidang. Seiring dengan perkembangannya, ada berbagai macam jenis Teknologi Informasi yang dapat dimanfaatkan. Animasi 3D (3 Dimensi) merupakan salah satu contoh Teknologi Informasi berbasis multimedia. Perkembangan industri kreatif pada bidang animasi terus berkembang. Menurut Dirjen Industri Kecil dan Menengah (IKM) Kemenperin Gati Wibawaningsih (2016), saat ini banyak tumbuh industri berbasis teknologi digital atau multimedia seperti animasi yang banyak dikerjakan oleh anak muda. Perkembangan industri animasi sudah semakin meluas dan semakin banyak animator-animator Indonesia yang handal dalam membuat film. film animasi saat ini telah berkembang sesuai dengan kebutuhan penggunanya, tidak semata untuk hiburan, melainkan juga untuk kepentingan promosi pelaku usaha maupun penyampaian informasi di kalangan pemerintah dan swasta. Kebutuhan animasi untuk kepentingan kebutuhan iklan, trik dalam film live sudah cukup terpenuhi. Bahkan untuk kebutuhan film live mancanegara pun trik melalui animasinya dilakukan oleh animator Indonesia. Bahkan banyak film animasi asing, termasuk yang beredar di Indonesia, ternyata dibuat oleh animator Indonesia. Ini menunjukkan kualitas animator kita mampu bersaing dengan animator dari luar negeri.

Universitas Sam Ratulangi (Unsrat) merupakan perguruan tinggi di Manado, Sulawesi Utara. Memiliki Sebelas Fakultas dan satu Program Pasca Sarjana serta dilengkapi dengan Visi dan Misi yang jelas, tidak menutup kemungkinan jumlah orang yang berminat untuk mendaftar di Unsrat baik dari dalam maupun dari luar daerah akan terus bertambah setiap tahunnya. Namun dari sekian banyak calon mahasiswa yang hendak mendaftar di Unsrat, tidak banyak yang mengetahui letak serta keadaan bangunan di Unsrat. Bukan hanya dari calon mahasiswa baru, bahkan masih banyak mahasiswa Unsrat sendiri yang masih belum begitu mengenal letak gedung-gedung di Unsrat.

Dengan pembuatan Animasi 3D mengenai gedung-gedung Unsrat di harapkan dapat membantu calon mahasiswa baru, maupun semua masyarakat agar bisa lebih paham mengenai letak bangunan di Unsrat beserta dengan fakultas-fakultasnya. Serta dapat menjadi media pengenalan kampus Unsrat

\section{LANDASAN TEORI}

A. Multimedia

Multimedia adalah penggunaan komputer untuk menyajikan dan menggabungkan teks, suara, gambar, animasi dan video dengan alat bantu (tool) dan koneksi (link) sehingga pengguna dapat bernavigasi, berinteraksi, berkarya dan berkomunikasi (Hofstetter, 2001). Multimedia sering digunakan dalam dunia hiburan. Selain dari dunia hiburan, Multimedia juga diadopsi oleh dunia Game. Multimedia juga dapat diartikan sebagai penggunaan beberapa media yang berbeda dalam menyampaikan informasi berbentuk text, audio, grafik, animasi, dan video. Menurut Binanto (2010), Ada tiga jenis multimedia, yaitu: multimedia interaktif, hiperaktif dan linier. 
1) Multimedia Interaktif: Pengguna dapat mengontrol apa dan kapan elemen - elemen multimedia akan dikirimkan atau ditampilkan.

2) Multimedia Hiperaktif : Multimedia jenis ini mempunyai suatu struktur dari elemen - elemen terkait dengan pengguna yang dapat mengarahkannya. Dapat dikatakan bahwa multimedia jenis ini mempunyai banyak tautan (link) yang menghubungkan elemen - elemen multimedia yang ada.

3) Multimedia Linear: Pengguna hanya menjadi penonton dan menikmati produk multimedia yang disajikan dari awal hingga akhir. Berdasarkan definisi tersebut, multimedia dapat digambarkan seperti pada gambar 1 .

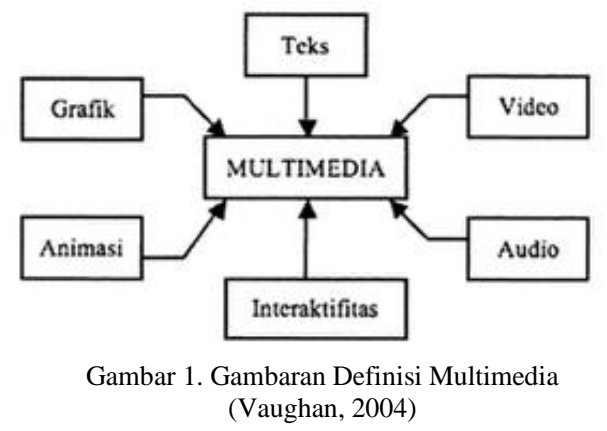

Dengan penggunaan multimedia, penyampaian informasi akan menjadi lebih menarik dan mempermudah pengguna dalam mendapatkan informasi tersebut. Seperti yang disebutkan dalam laporan hasil penelitian yang dikeluarkan oleh Computer Technology Research (Hofstetter, p4) seseorang hanya akan mendapatkan $20 \%$ dari apa yang mereka lihat dan $30 \%$ dari yang mereka dengar. Sedangkan melalui multimedia akan mendapatkan $50 \%$ dari apa yang mereka lihat dan dengar, sampai $80 \%$ dari apa yang mereka lihat, dengar dan berinteraksi dengan pada waktu yang sama.

\section{B. Animasi}

Animasi adalah simulasi gerakan yang dihasilkan dengan menayangkan rentetan frame ke layer. Frame adalah satu gambar tunggal pada rentetan gambar yang membentuk animasi. Animate adalah untuk membuat sesuatu hidup, sebagian orang mengira bahwa animasi itu sama dengan motion (gerakan), tetapi animasi mencakup semua yang mengandung efek visual sehingga animasi mencakup perubahan posisi terhadap waktu, bentuk, warna, struktur, tekstur dari sebuah objek, posisi kamera, pencahayaan, orientasi, fokus dan perubahan dalam teknik rendering (Foley et al, 1996, p. 1057). Penggunaan Animasi : Dunia Perfilman, periklanan, video klip, game, ilustrasi berbagai kejadian. Menurut Djalle (2007), Teknik yang digunakan untuk membuat animasi makin beragam. Dalam dunia animasi kita mengenal beberapa istilah yang bertujuan untuk membedakan jenis teknis pembutan animasi. Yaitu:

1) Animasi 2 Dimensi: Jenis animasi yang lebih dikenal dengan film kartun pembuatannya menggunakan teknik animasi hand draw atau animasi sel, penggambaran langsung film secara digital. Terdapat dua cara pembuatannya, yaitu manual dan komputer. Teknik animasi manual atau dengan cell animation adalah teknik animasi yang paling lama usianya. Teknik animasi ini memungkinan animator untuk membuat gambar pada lembaran celuloid (lembar trasparan) yang berlapis-lapis. karena kemajuan teknologi sekarang, animator menggunakan kertas biasa yang nanti akan di pindai (scan) lalu di warna dengan menggunakan computer

2) Animasi 3 Dimensi : Tiga Dimensi (3D) merupakan dimensi yang memiliki tiga unsur dimensi yaitu panjang, lebar, dan juga tinggi. Benda-benda 3D dapat bergerak bebas ke arah kanan, kiri, atas, bawah, depan, dan belakang. Bendabenda 3D sering juga disebut dengan istilah bangun ruang. Salah satu ciri utama 3D adalah dapat diisi dengan benda benda tertentu atau dengan kata lain memiliki volume. Beberapa contoh benda 3D yaitu balok, kubus, tabung, kerucut, rumah, mobil, hewan, manusia, dan lain-lain. Disebut tiga dimensi (3D) karena jenis ini memiliki sifat kedalaman atau ruang pada objeknya. Secara sepintas akan mudah mengenali film animasi dengan jenis tiga dimensi ini. karena bentuknya yang halus, pencahayaan yang lebih real dan kesan ruang yang lebih terasa. Semua itu bisa dilakukan karena dibantu dengan teknologi komputer masa kini yang sudah canggih. dalam jenis animasi ini objek yang akan dianimasikan bisa dilihat dari semua sudut atau sisinya. seperti halnya boneka sungguhan namun objek dibuat secara digital dengan menggunakan software khusus.

3) Animasi Stopmotion: Teknik animasi yang menggabungkan teknologi fotografi dengan animasi. media yang digunakan bisa bermacam-macam. misalnya boneka, kertas, gambar dikertas, gambar di papan tulis, lilin/malam, dan lain-lain. semua objek itu bisa dijadikan sebagai objek animasi yang nantinya akan di foto tiap gerakannya

\section{Film Animasi}

Film animasi berasal dari dua unsur, yaitu film yang berakar pada dunia fotografi dan animasi yang berakar pada dunia gambar. Menurut Sumarno (1996), Dari beberapa bentuk film, film animasi di Indonesia mulai muncul pada tahun 1955 dengan judul Si Doel karya Dukut Hendronoto, dilanjutkan oleh stasiun TVRI. Hingga tahun 1970-an, film animasi semakin bermunculan, ditandai oleh film Si Huma yang cukup fenomenal. Dalam Film Animasi terdapat beberapa unsur penting yang mendukung terbentukanya suatu film Animasi. Salah satu diantaranya adalah video. Video Menurut Kamus Besar Bahasa Indonesia (2016), Video merupakan bagian yg memancarkan gambar pada pesawat televisi; rekaman gambar hidup atau program televisi untuk ditayangkan lewat pesawat televisi.

\section{Unsrat}

Universitas Sam Ratulangi atau yang di singkat UNSRAT adalah salah satu perguruan tinggi negeri di Indonesia yang berlokasi di Kota Manado, provinsi Sulawesi Utara. Universitas Sam Ratulangi dipimpin oleh Prof. Dr. Ir. Ellen Joan Kumaat, M.Sc., DEA.

\section{1) Visi Unsrat}

Visi Universitas Sam Ratulangi jangka panjang adalah Bersama menata Universitas Sam Ratulangi menjadi universitas unggul dan berbudaya. Visi ini adalah visi jangka panjang dengan pemahaman bahwa "universitas unggul dan berbudaya" bersifat relatif terhadap tahapan waktu. Selain itu, 
E-journal Teknik Informatika vol.? no.?, bulan ? - bulan ? 2016, ISSN: 2301-8364

universitas unggul dan berbudaya dapat berlaku pada wilayah lokal, nasional, regional dan selanjutnya internasional. Visi ini akan terus diperjuangkan selama universitas ini berdiri.

\section{2) Misi Unsrat}

Misi 1, Meningkatkan kualitas Tridharma PT secara berkelanjutan dimaksudkan untuk peningkatan kualitas program Pendidikan, Penelitian, dan Pengabdian pada masyarakat mulai dari proses perencanaan, penyelenggaraan/implementasi, pelaporan, monitoring, dan evaluasi melalui standar terukur terhadap tahap masukan (input), proses (process), hasil (output), dan dampak (outcomes).

Misi 2, Mengembangkan Inovasi dalam Ilmu Pengetahuan, Teknologi dan Seni-Budaya yang berorientasi Kawasan Pasifik, dimaksudkan untuk peningkatan daya saing melalui penguasaan dan pemanfaatan ilmu pengetahuan dan inovasi teknologi yang memiliki relevansi dengan posisi geografis kawasan dimana UNSRAT berada.

Misi 3, Meningkatkan Akses dan peran PT bagi peningkatan Taraf dan Kualitas hidup Masyarakat, dimaksudkan untuk peningkatan akses belajar di perguruan tinggi, dan pemerataan mengecap pendidikan tinggi, serta meningkatkan peran dalam perekonomian masyarakat melalui peluang kerjasama dan kemitraan demi peningkatan taraf dan kualitas hidup masyarakat.

Misi 4, Meningkatkan Tatakelola Pendidikan Tinggi, dimaksudkan untuk menata UNSRAT menuju institusi dengan sistem tatakelola PT yang otonom, akuntabel, efektif dan efisien dalam penyelenggaraan fungsi-fungsi institusi.

(www.unsrat.ac.id, Diakses pada 3 Juli 2015)

Universitas Sam Ratulangi sebagai perguruan tinggi negeri dengan Sebelas Fakultas dan satu Program Pasca Sarjana. Gambar 2 merupakan tampilan lokasi Unsrat dari atas yang diambil menggunakan Google Earth. Garis berwarna hitam menunjukkan batas wilayah Unsrat, sedangkan nomor menunjukkan sebagian besar gedung-gedung yang ada di Unsrat.

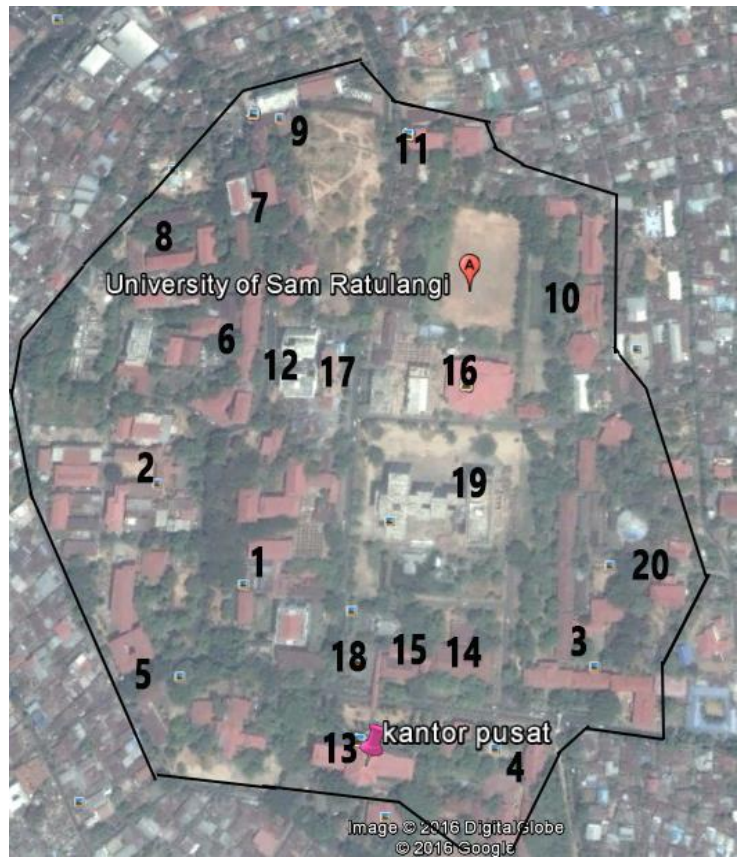

Gambar 2. Peta Universitas Sam Ratulangi via Google Earth
Nama-nama Gedung sesuai dengan nomor:

1 Fakultas Kedokteran

2 Fakultas Teknik

3 Fakultas Pertanian

4 Fakultas Peternakan

5 Fakultas Perikanan dan Ilmu Kelautan

6 Fakultas Ekonomi

7 Fakultas Hukum

8 Fakultas Ilmu Sosial dan Ilmu Politik

9 Fakultas Sastra

10 Fakultas Matematika dan Ilmu Pengetahuan Alam

11 Fakulas Kesehatan Masyarakat

12 Program Pasca Sarjana

13 Kantor Pusat

14 Perpustakaan

15 PTI

16 Auditorium

17 Lembaga Penelitian dan Pengabdian kapada Masyarakat (LPPM)

18 Patung Sam Ratulangi

19 Poliklinik

20 Lembaga Pembinaan dan Pengembangan Pembelajaran (LPPP)

\section{E. Tahap Pembuatan Film Animasi 3D}

Dalam Tahap pembuatan Film Animasi 3D terdapar 3 tahap utama yaitu Pra Produksi, Produksi, dan Pasca Produksi. Pada tahap Pra produksi, langkah pertama yaitu penentuan Ide dan Tema, selanjutnya proses Pengumpulan Data, kemudian pembuatan Storyboard/Rancangan alur cerita. Setelah Pra Produksi, masuk pada tahap Produksi, terdapat 5 proses, Modeling, Texturing, Compositing Object, Animating, Rendering. Tahap terakhir yaitu Pasca Produksi. Diawali dengan Compositing, dapat berupa rekaman suara atau musik, Final Editing, Rendering, hingga Film Animasi. Tahap pembuatan Film Animasi 3D dapat dilihat pada Gambar 3.

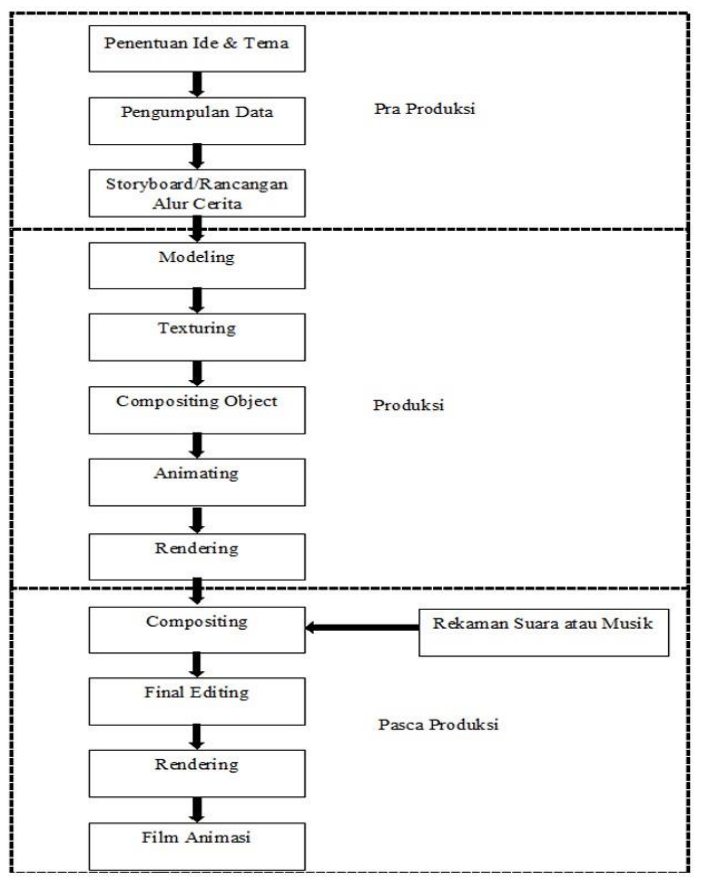

Gambar 3. Tahap pembuatan Film Animasi 3D (Buchari, 2015) 


\section{METODOLOGI PENELITIAN}

\section{A. Waktu dan Tempat Penelitian}

Adapun penelitian ini dilaksanakan dalam rangka penyusunan tugas akhir dengan judul Rancang Bangun Film Animasi 3D Universitas Sam Ratulangi. Waktu penelitian dimulai dari 5 Juli 2016 - Oktober 2016 dengan mengambil lokasi di Universitas Sam Ratulangi Manado.

\section{B. Analisis Kebutuhan Sistem}

1) Kebutuhan Perangkat Keras : Kebutuhan Perangkat Keras atau hardware yang digunakan pada proses pembuatan Film Animasi 3D Universitas Sam Ratulangi adalah Intel® CoreTM i7-4510U CPU @ 2.00GHz (4 CPUs), 2.6GHz, 8GB DDR3 memory, 1000GB HDD, NVIDIA® GeForce ${ }^{\circledR}$ 920M with 2GB Dedicate VRAM, Mouse Logitech M187

2) Kebutuhan Peangkat Lunak : Kebutuhan Perangkat Lunak dalam Pembuatan Film Animasi 3D Unsrat adalah Sistem Operasi Windows 8.1 Pro 64-bit, Blender 2.71, Adobe Premiere Pro CS6

\section{Pra Produksi}

Pra Produksi merupakan tahap awal, berisi 3 bagian yaitu penentuan ide dan tema, pengumpulan data, dan storyboard.

1) Penentuan Ide dan Tema: Penentuan Ide dan Tema dimulai ketika penulis melihat masih banyak mahasiswa Unsrat yang belum begitu paham mengenai letak gedunggedung dan fakultas-fakultas yang lain, di tambah lagi calon mahasiswa baru yang masih sangat kebingungan dan tidak tahu dimana letak gedung yang akan mereka tuju di Unsrat. Berdasarkan pengamatan yang di lakukan di Unsrat dan hasil dari konsultasi dengan beberapa dosen, sehingga mendapatkan judul Skripsi Rancang Bangun Film Animasi 3D Universitas Sam Ratulangi

2) Pengumpulan Data: Pengumpulan data dilakukan untuk memperoleh informasi yang dibutuhkan dalam rangka mencapai tujuan penelitian.

\section{a. Observasi dan Dokumentasi}

Proses Observasi dan Dokumentasi dilakukan di Universitas Sam Ratulangi dengan mengambil gambar gedung-gedung secara langsung dan juga mengambil gambar miniatur atau maket Universitas Sam Ratulangi

\section{b. Kuisioner}

Penulis telah menyebarkan 2 macam kuisioner. Yang pertama 38 buah yang telah disebarkan kepada mahasiswa Unsrat, dan yang kedua 36 buah untuk masyarakat dan calon mahasiswa baru Unsrat. Tujuan penulis membuat dan mengedarkan kuisioner ini adalah untuk mengetahui seberapa dalam pengetahuan para responden dalam hal ini melibatkan mahasiswa Unsrat, calon mahasiswa baru Unsrat dan masyarakat melalui pertanyaan-pertanyaan seputar Unsrat serta bangunan-bangunan yang ada di dalamnya.

\section{c. Studi Pustaka}

Penulis telah membaca buku-buku referensi dan paper-paper pendukung serta mengambil referensi beberapa situs resmi dari internet
3) Storyboard : Storyboard atau rancangan alur cerita dibuat agar nantinya proses pengerjaan film animasi 3D ini akan menjadi lebih mudah dan terarah. Gambar 4 menampilkan gabungan dari tiap scene yang akan di tampilkan pada Film Animasi 3D Unsrat. Jumlahnya ada 16 scene.

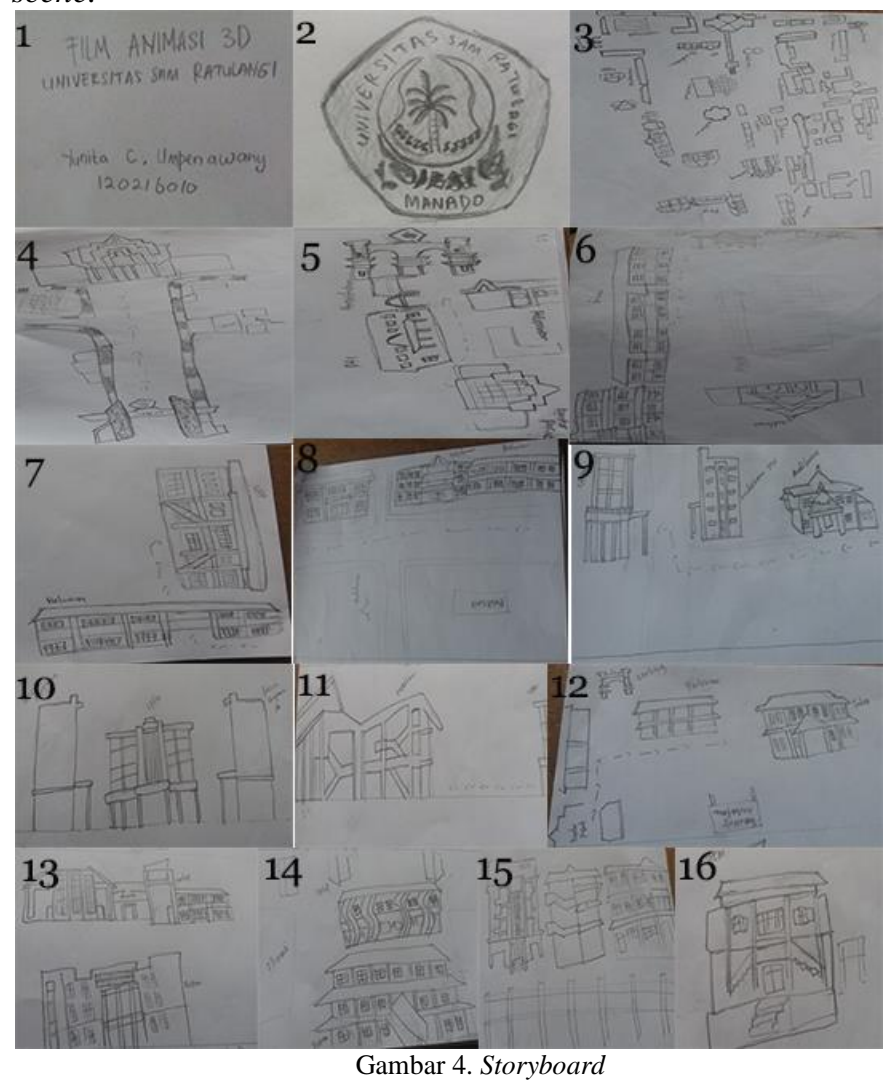

\section{Produksi}

Pada tahap Produksi terdiri dari Modeling, Texturing, Compositing Object, Animating, dan Rendering

1) Modeling : Modeling adalah proses pembuatan sebuah objek. Dimana proses pembuatan objek ini menggunakan tools pada blender. Seperti tools mesh yang terdiri dari plane, cube, circle, UV sphere, iconsphere, cylinder, cone, grid, monkey dan lain- lain yang bisa dipakai untuk memodelkan sebuah objek sesuai yang di inginkan. Pada Gambar 5 dapat dilihat proses modeling Kantor pusat Unsrat

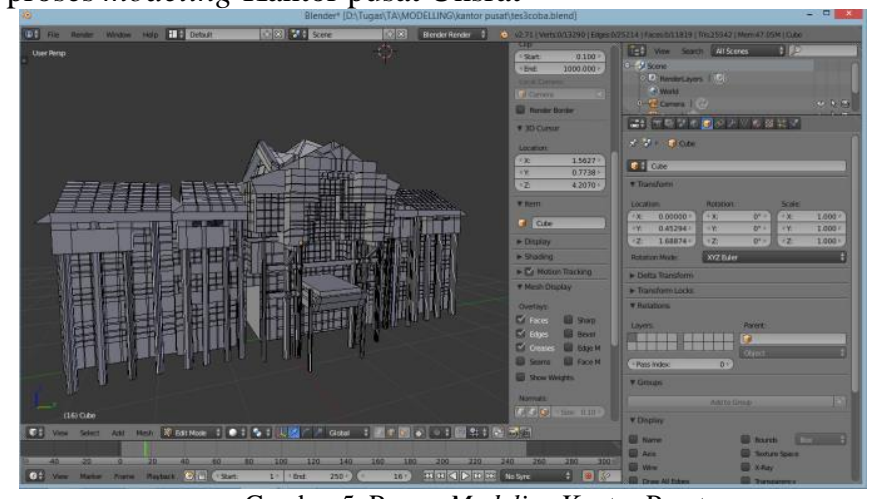

Gambar 5. Proses Modeling Kantor Pusat 
E-journal Teknik Informatika vol.? no.?, bulan ? - bulan ? 2016, ISSN: 2301-8364

2) Texturing: Texturing adalah proses pemberian texture atau material pada sebuah objek sehingga menjadi sesuai dengan yang kita inginkan. Proses texturing pada program blender dapat dibuat dengan menggunakan tools material dan tools texture. Dapat dilihat pada Gambar 6 menunjukkan Proses texturing atau pewarnaan Gerbang masuk utama Unsrat yang menggunakan warna dasar abu-abu muda dengan warna hitam, cokelat muda, cokelat tua, abu-abu tua untuk memberikan efek bebatuan di bagian tengah. Untuk Lambang Unsrat dikepala Gerbang menggunakan plane kemudian tarik gambar kedalam plane. Setelah itu centang face textured pada tools Material sehungga gambar pada plane dapat muncul ketika di render, sedangkan tulisan Universitas Sam ratulangi pada kepala pintu gerbang menggunakan tools text

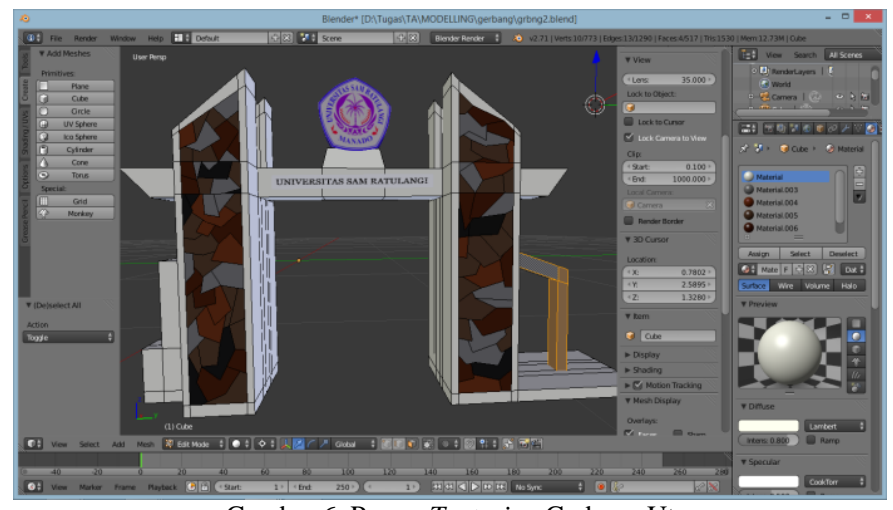

Gambar 6. Proses Texturing Gerbang Utama

3) Compositing Object : Compositing object merupakan proses penyatuan, penempatan objek atau karakter yang dibuat terpisah. Dengan meng-import file-file objek yang telah dibuat lalu disesuaikan dengan adegan yang telah dirancang. Gambar 7 menunjukkan Proses Compositing atau penggabungan objek-objek diantaranya gedung-gedung, rumput, jalan, serta pepohonan pada salah satu scene. Scene tersebut bertugas menampilkan seluruh bangunan di Unsrat sehingga penulis meng-import seluruh objek yang telah dibuat sebelumnya.

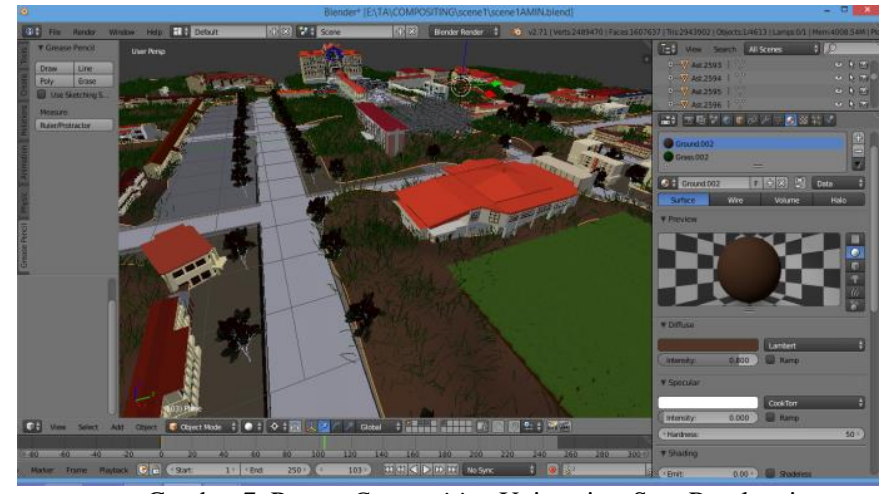

Gambar 7. Proses Compositing Universitas Sam Ratulangi

4) Animating : Animating merupakan pergerakan objek animasi melalui keyframe. Film Animasi Unsrat ini menggunakan pengoperasian Camera Tracking yang merekam objek-objek yang ada dengan pergerakan kamera sehingga menampilkan pandangan kamera yang berjalan. Bentuk Keyframe berupa beberapa titik yang berada pada Timeline yang berfungsi menyimpan hasil rekaman yang berasal dari kamera. Tiap titik ditempatkan berdasarkan waktu objek direkam. Pada Gambar 8 dapat dilihat pada bagian dope sheet sebelah kiri, terdapat key frame. Sedangkan di sebelah kanan tampilan $3 D$ view, terdapat kamera sementara merekam.

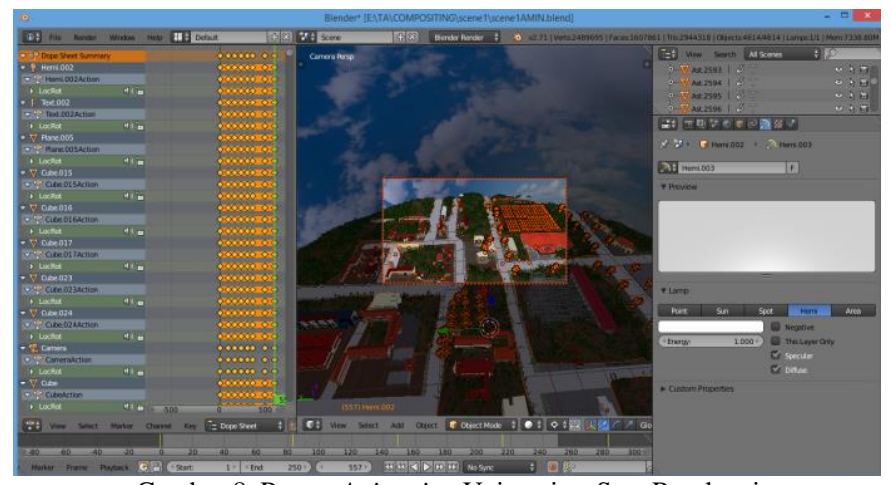

Gambar 8. Proses Animating Universitas Sam Ratulangi

5) Rendering : Rendering merupakan tahap akhir dari produksi. Proses Rendering menyatukan seluruh proses dalam tahap produksi, mulai dari Modeling sampai Animating sehingga menghasilkan sebuah file video. Proses Rendering pada tahap Produksi masih menggunakan aplikasi blender dimana dapat me-render image, video, maupun audio. Pada Gambar 9 menunjukkan proses rendering gedung fakultas Ilmu Sosial dan Ilmu Politik yang terdapat dalam salah satu scene. Sebelum render, pilih awal dan akhir frame yang akan di render yang terletak dibagian bawah. Kemudian pilih folder destinasi tempat file yang akan disimpan, pilih format File yang diinginkan. Pada penelitian ini penulis menggunakan format MPEG.

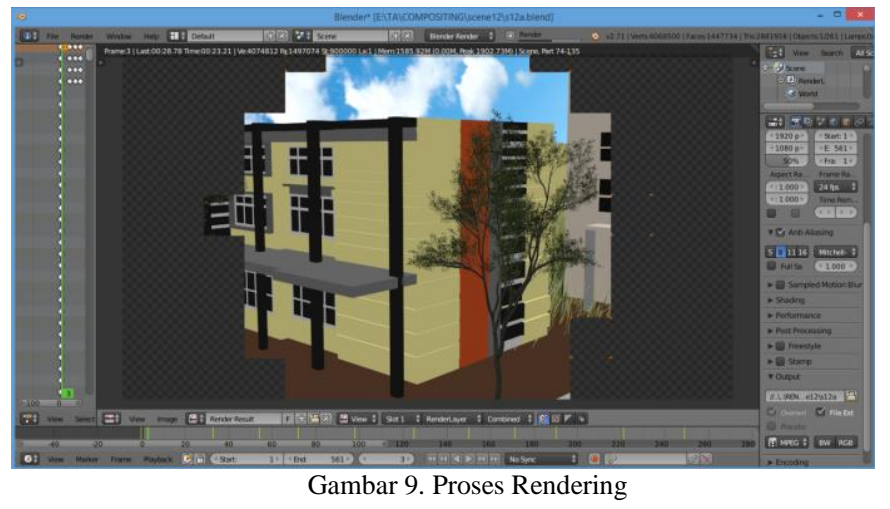

\section{HASIL DAN PEMBAHASAN}

Pada bab ini akan dibahas sisa dari metodologi yang digunakan, yaitu tahap pasca produksi

\section{A. Pasca Produksi}

Produksi merupakan bagian terakhir dari pembuatan Film. Terdapat beberapa bagian penting pada tahap Produksi mencakup compositing, Final Editing, Rendering, Film Animasi

1) Compositing: Compositing merupakan penggabungan dari beberapa elemen seperti video hasil dari rendering animasi beserta seluruh bagiannya, gambar atau image juga audio. Sehingga dapat menghasilkan suatu output film. Proses 
E-journal Teknik Informatika vol.? no.?, bulan ? - bulan ? 2016, ISSN: 2301-8364

pada tahap ini dapat dilihat pada Gambar 10. Kegiatan dilakukan dalam aplikasi pengedit video Adobe Premiere.

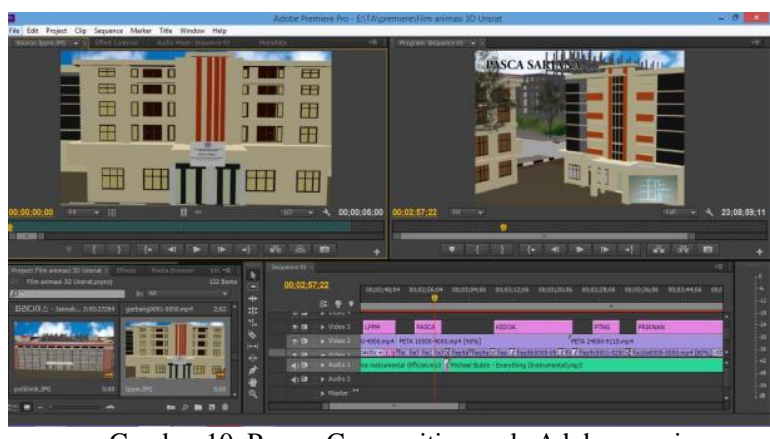

Gambar 10. Proses Compositing pada Adobe premiere

Pada Gambar 11 menunjukkan Track audio dalam Adobe Premiere dimana kumpulan musik instrumental yang kemudian digabungkan bersama-sama dengan video, text, gambar kemudian di akan edit.

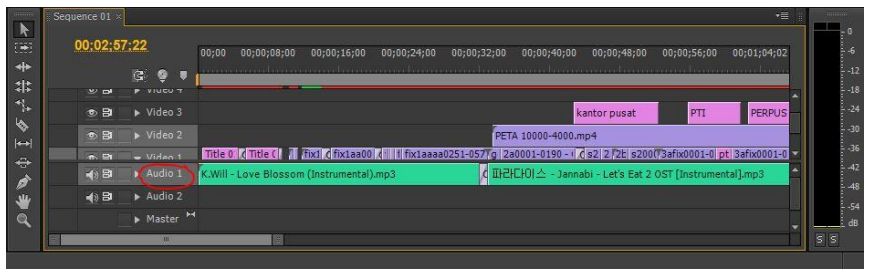

Gambar 11. Proses Compositing Musik pada Adobe premiere

2) Final Editing: Final Editing merupakan proses pengecekan alur cerita apakah sudah sesuai dengan storyboard ataupun hasil yang diinginkan. Seperti pada Gambar 12, semua file telah digabungkan dan di edit. Penulis memeriksa kembali apakah semua sudah sesuai dengan yang diinginkan dan penulis melihat kembali storyboard yang telah dibuat sebelumnya pada Gambar 4. Apabila belum sesuai, penulis dapat mengeditnya kembali dan jika sudah sesuai, penulis dapat lanjut ke tahap berikutnya.

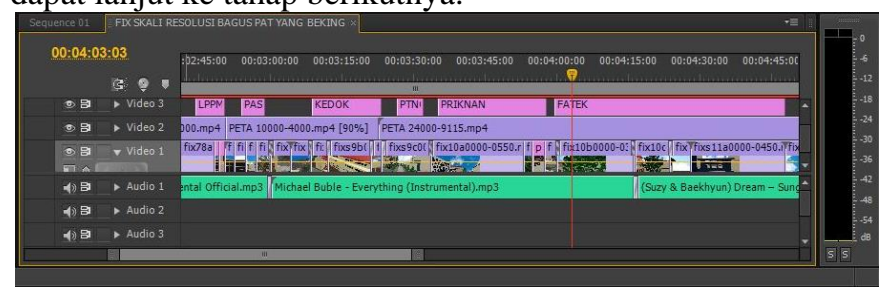

Gambar 12. Proses Final Editing

3) Rendering : Rendering merupakan proses untuk membuat semua file hasil dari compositing dan editing video di render kembali menjadi satu film utuh. Gambar 13 menampilkan Proses rendering video pada Adobe Premiere

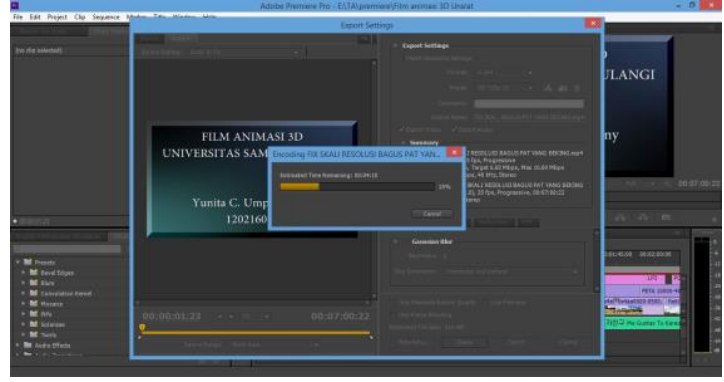

Gambar 13. Proses Rendering pada Adobe premiere
4) Film Animasi : Film Animasi merupakan hasil (output) setelah semua tahap selesai. Setelah melewati semua proses dari awal hingga pembuatan Film Animasi 3D Unsrat yang diawali dengan modeling pada aplikasi Blender sampai dengan proses yang terakhir yaitu rendering dengan menggunakan aplikasi Adobe premiere, akhirnya dapat menghasilkan Film Animasi 3D dengan format .MP4 beresolusi $1280 \times 720$ pixel durasi film selama 7 menit dan ukuan file 307 MB. Dapat dilihat opening film dimana menampilkan judul film, nama dan nim dari penulis pada Gambar 14 dibawah ini.

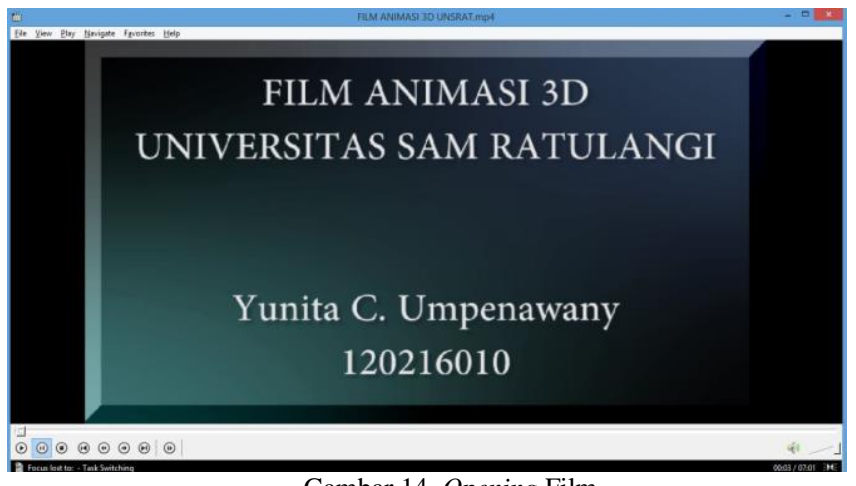

Gambar 14. Opening Film

\section{PENUTUP}

\section{A. Kesimpulan}

Setelah menyelesaikan proses pembuatan Film Animasi 3D Unsrat ini, maka penulis dapat mengambil beberapa kesimpulan sebagai berikut :

1. Melalui penelitian ini, gedung dan patung di Unsrat dapat didesain dan ditampilkan secara realistis dalam bentuk 3D menggunakan Blender.

2. Penelitian ini menghasilkan Film Animasi 3D Universitas Sam Ratulangi

3. Penelitian ini dapat menjadi wadah pengenalan kampus Unsrat.

\section{B. Saran}

penulis memiliki beberapa saran yang diharapkan dapat membantu mempermudah pembuatan skripsi dalam bidang multimedia selanjutnya, antara lain:

1. Gunakan hardware yang memadai, komputer cluster, mengingat semakin banyak objek yang ditampilkan, maka semakin lambat poses rendering berjalan.

2. Lakukan observasi serta dokumentasikan melalui foto objek yang akan di modeling agar hasilnya bisa mirip dengan yang asli ataupun sesuai dengan yang diinginkan

3. Untuk peta pada animasi, gunakan latar dari google earth atau tampilan peta lainnya yang lebih real

\section{DAFTAR PUSTAKA}

[1] Situs Resmi Kamus Oxford, tersedia www.oxfordlearnersdictionaries.com. Diakses pada tanggal 27 Setember 2016.

[2] Situs Resmi Kementrian Perindustrian, tersedia www.kemenperin.go.id. Diakses pada tanggal 22 Oktober 2016. 
E-journal Teknik Informatika vol.? no.?, bulan ? - bulan ? 2016, ISSN: 2301-8364

[3] Hofstetter, T. Fred. (2001), Multimedia Literacy, 3rd Ed. Irwin/McGraw-Hill. New York.

[4] Binanto, I. (2010), Multimedia Digital - Dasar Teori dan Pengembangannya. Penerbit Andi . Yogyakarta.

[5] Vaughan, T. (2004), Multimedia making it work. Penerbit Andi. Yogyakarta.

[6] Hofstetter, T. Fred. (1994), Is Multimedia the nextliteracy? Educators' Tech Exchange, Winter.

[7] Foley, J. D. (1996), Computer Graphics Principled and Practice. J. Siveri. Boston.

[8] Djalle, Z. G. (2007), The Making of 3D Animation Movie Using 3Dstudio Max. Informatika. Bandung.

[9] Sumarno, M. (1996), Dasar-Dasar Apresiasi Film. Gramedia Widiasarana. Jakarta.

[10] Situs Resmi Kamus besar bahasa Indonesia, tersedia : www. kbbi.web.id. Diakses pada tanggal 3 Mei 2015.

[11] Situs Resmi Unsrat, tersedia: www. unsrat.ac.id. Diakses pada tanggal 3 Juli 2015.

[12] Suratinoyo, H. S. (2013), Cerita Rakyat Daerah Minahasa : Implementasi Short Film Animasi 3D, Teknik Informatika Universitas Sam Ratulangi, Vol 2, No.2.

[13] Rompas, M. V.(2013), Perancangan Gedung Fakultas Teknik Unsrat Dengan Perspektif Animasi 3D, Teknik Informatika Universitas Sam Ratulangi, Vol 2, No.2.

[14] Firdaus, S. (2012), Perancangan Aplikasi Multimedia Interaktif Company Profile Generic (Studi Kasus CV. GANETIC), Vol 9.

[15] Buchari, M. Z. (2015), Rancang Bangun Video Animasi 3 Dimensi Untuk Mekanisme Pengujian Kendaraan Bermotor di Dinas Perhubungan, Kebudayaan, Pariwisata, Komunikasi dan Informasi, Skripsi, Program S1 Teknik Elektro Universitas Sam Ratulangi. Manado.

[16] Nari, J. S. (2014), Perancangan Studio Musik Bambu Dengan Perspektif Animasi 3D, Skripsi, Program S1 Teknik Elektro Universitas Sam Ratulangi. Manado.

\section{TENTANG PENULIS}

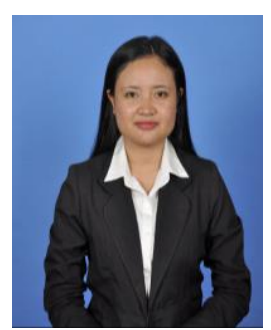

Sekilas dari penulis dengan nama Yunita Caroline Umpenawany, anak bungsu dari empat bersaudara. Lahir di Tidore, tanggal 8 Juni 1995. Dengan alamat sekarang Kelurahan Tingkulu Lingkungan 4 Lorong 1 komplek Gereja HKBP No.39 Kecamatan Wanea. Sekolah pertama tempat belajar adalah SD Kartika VII-3 Manado. Kemudian melanjutkan pendidikan ke SMP N 7 Manado, dan melanjutkan pendidikan ke SMA N 7 Manado. Pada tahun 2012, Penulis melanjutkan studi di Fakultas Teknik, Jurusan Elektro, Program Studi Informatika, Universitas Sam Ratulangi Manado. Kemudian pada tahun 2015 bulan Agustus penulis membuat skripsi demi memenuhi syarat Sarjana (S1) dengan penelitian berjudul "Rancang Bangun Film Animasi 3D Universitas Sam Ratulangi" dengan pembimbing I Virginia Tulenan, S.Kom, MTI dan pembimbing II Brave A. Sugiarso, ST., MT,. Sehingga pada tanggal 28 Oktober 2016 penulis resmi lulus di Teknik Informatika Universitas Sam Ratulangi dan menyandang gelar sebagai Sarjana Komputer. 